Journal of the Rubber Research Institute of Sri Lanka, (2009) 89, 58-69

\title{
Rural livelihood and rubber cultivation in Eastern province of Sri Lanka
}

\author{
V H L Rodrigo*, S M M Iqbal* and E S Munasinghe*
}

Received 07 December 2009; Accepted 12 February 2010

\begin{abstract}
With no sufficient land available for further cultivation of rubber in its traditionally grown wet areas to meet the increasing demand, the Government of Sri Lanka has targeted moderately dry areas of the country for the same. In collaboration with the peasant community, rubber is to be grown under rain fed condition together with traditional crops in these regions. Being a perennial crop which provides a long term source of income, an upliftment of rural livelihood is also expected in this exercise. Moreover, tree cover of the country is to be increased. In line with the country needs, rubber was established for the first time in the Intermediate zone of Eastern province with some farmers in a selected village. Since initial agronomic assessments were in favour of rubber cultivation in this region, a rapid livelihood analysis was carried out in the village to assess the association of this intervention with rural livelihood.

Agricultural activities were confined to two seasons associated with a unimodel rainfall pattern. Strong socio-cultural interactions have made the rural livelihood rather sustainable. However, it operated at a low level in monitory terms with annual income and expenditure of a family in the range of Rs.55,000/=. Due to the dependency on seasonal crops, the income varied largely from month to month. Except for March - April and October - November, the income of the majority from agriculture was limited a value less than Rs.2,500 per month. Expenditure was mainly on subsistence and agriculture related activities and, generally below Rs.6,000 per household per month in most instances. Traditional New Year celebration in April and religious activities in May and June required an additional of ca. Rs.9,000.

Demand for labour in rubber was year-round but not as high as for seasonal crops. There was a competition between rubber and other crops for labour at the beginning of Maha season (September to November), if rubber planting was undertaken. Farmers mostly planted rubber in an area of 0.2 to 0.4 ha in one occasion and also with traditional seasonal crops hence time allocation to rubber had no drastic impact on subsistence agriculture. Coping mechanisms of the society and the strategies to be placed in development programmes are also discussed.
\end{abstract}

Key words: dry areas, intercropping, rubber, rural livelihood, smallholder

* Rubber Research Institute of Sri Lanka, Dartonfield, Agalawatta, Sri Lanka 
V H L Rodrigo et al.

\section{Introduction}

In Sri Lanka, rubber based industries are booming up with that total amount of foreign exchange earning from rubber based products is greater than that from raw rubber exports (Ministry of Plantation Industries, 2008). However, there is virtually no potential for further expansion of the rubber cultivation in its traditional growing area, i.e. Wet zone, since lands in this region are highly subjected to urbanization and industrialization. With the risk of establishing rubber in the Dry zone of the country (mean annual rainfall $<1750 \mathrm{~mm}$, Punyawardena, 2005), the Government of Sri Lanka (GoSL) has targeted the Intermediate zone (mean annual rainfall 1750-2500 $\mathrm{mm}$, Punyawardena, 2005) in the south east of the island for future expansion of rubber cultivation. Whilst the extent of smallholder rubber cultivation in the Intermediate zone is presently less than 6000 ha (unpublished information from the Rubber Development Department), rubber was originally grown in this region at the time of its introduction to Sri Lanka in 1876 (Amaraweera, 1976). Annual rainfall in the Intermediate zone is sufficient for rubber growth but the existence of distinct dry seasons means that quality of management practices is far more critical to the successful establishment of the crop compared to the traditional rubber growing regions in the Wet zone. Water availability for irrigation is very limited in this region and where it is available, those lands are devoted for more remunerative short term cash crops. Therefore, rubber is to be grown under rain fed conditions.

Being a war-torn area, Eastern province has currently been targeted for development programmes by the government of Sri Lanka. It comprises large extent of sparsely populated land indicating the potential for establishing plantation crops like rubber. Population density in Eastern province is 144 persons $/ \mathrm{km}^{2}$ and $26 \%$ of agricultural lands in the country are in this region. Also, more women in the region are unemployed with an unemployment rate 21.1\% (Central Bank of Sri Lanka, 2006). In Eastern province, suitable area for initial cultivation of rubber is obviously the Intermediate zone which covers two administrative regions, i.e. area under Padiyatalawa and Mahaoya divisional secretariats (Rodrigo et al., 2007). Rubber has been cultivated in an area of over 40 ha with smallholder farmers on trial basis since 2003. Records on growth performance to date are in favour of the suitability of rubber to the area concerned. For instance, the mean survival of rubber plants for all sites established was recorded as $75 \%$ together with an annual mean plant girth expansion rate of $7.44 \mathrm{~cm}$ (Iqbal and Rodrigo, 2006; Rodrigo and Iqbal, 2006). A SWOT analysis carried out in the area confirmed the availability of sufficient lands for rubber and more importantly, farmers have very high interest in rubber cultivation (Rodrigo and Iqbal, 2009). Nevertheless, socio economic and cultural factors associated with rural livelihood need to be assessed 
Rural livelihood and rubber cultivation

together with climatic conditions particularly before any large scale programme on rubber cultivation. Therefore, the study reported here was aimed to characterize existing cropping calendars, micro economy in households and to understand how best rubber can improve the wellbeing of the community thorough a detailed livelihood analyses.

\section{Methodology}

Farmers who had been engaged in and expected to be engaged in rubber farming in Eastern province were called for the workshop on livelihood analyses. Farmers gathered in a homestead of a rubber smallholder in Helakomana village in August, 2007. In total, 79 farmers participated in the workshop with 57 males and 22 females. Three researchers including a female together with one technical assistant were involved in conducting the workshop.

Livelihood analyses comprised with 3 steps. Firstly, farmers' knowledge on regional climate was gathered. In particular, rainfall distribution which is the most important climatic parameter in farming community was established with farmers' knowledge on rainy days in calendar month. Secondly, the cropping calendar of the region was established and farmers' time allocation on agricultural activities in each calendar month was assessed under three categories, i.e. less than 10, 10-20 and above 20 days per month. Finally, seasonal expenditure and income pattern of farmers was assessed. It was difficult to differentiate the expenditure on subsistence and agriculture and hence assessed together. Considering the minimum and maximum level of expenditure, three expenditure categories were set in this regard as, $c a$. Rs.2,000/=, Rs.2,000 - 4,000/= and Rs.4,000 - 6,000/= and number of farmers falling into each category was assessed. Further, other occasional expenditure items were evaluated. The income was mainly from the sale of agricultural produce. Unlike for expenditure, same way of categorization of income was not applicable to every month hence higher level of categorization had to be used for the months associated with harvesting. Farmers were openly questioned under each item and their opinions were recorded in a flip chart mounted in front of them. This was followed by an open discussion to reach the final consensus. This assessment was a full day interactive programme and so, foods were provided. All participants were quite enthusiastic to be engaged in the study.

\section{Results}

Rainfall has spread out mainly from October to February with above 10 rainy days per month (Fig. 1). The highest rainfall was recorded in December having rains almost in everyday of the month. The period from May to August was quite dry and 
V H L Rodrigo et al.

virtually, there was no rain in June and July.

Despite some variations, it was possible to identify major seasons of the main crops grown in this region. Short term crops were generally cultivated in two seasons with different time frames (Table 1). The main season of maize began in mid August and lasted till the end of the year. Again in some instances, maize was cultivated from February to May. Activities related to cultivation of cowpea, green gram and groundnut were from mid July to the end of October and then from January to April. Upland paddy was cultivated from November to following year March whilst millet was from December to April. Cultivation of vegetables was restricted to four months starting from August and chilli for five months from November. Lime and orange were the main perennial crops in this village and their harvesting and intercultivation activities (weeding) spread out from
January to April. Being a newly introduced perennial crop, people were involved in cultivation activities of rubber throughout the year.

Except in May and June, all farmers were involved in agricultural activities over 10 days per month and particularly in the months of August, October and November, the involvement of the majority were over 20 days per month (Table 2). Activities other than agriculture mainly referred to the religious work and social commitments. In general, farmers allocated 2-3 days per month for the former. Time allocation for latter was about five days and never exceeded ten days per month. Involvement in rubber cultivation has been spread out throughout the year with about 5.5 days per month (Table 3). The highest demand for labour in rubber was recorded in November due to its planting in new clearings.

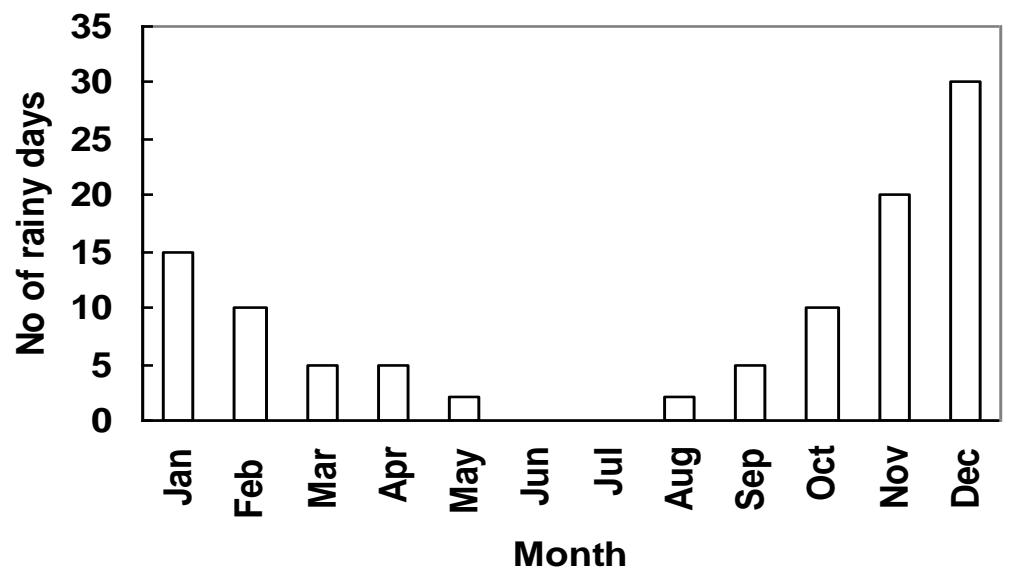

Fig. 1. Monthly rainfall distribution of the rubber growing area of Eastern province 
Rural livelihood and rubber cultivation

Table 1. Cropping calendar adopted by the farmers in the rubber growing area of Eastern province

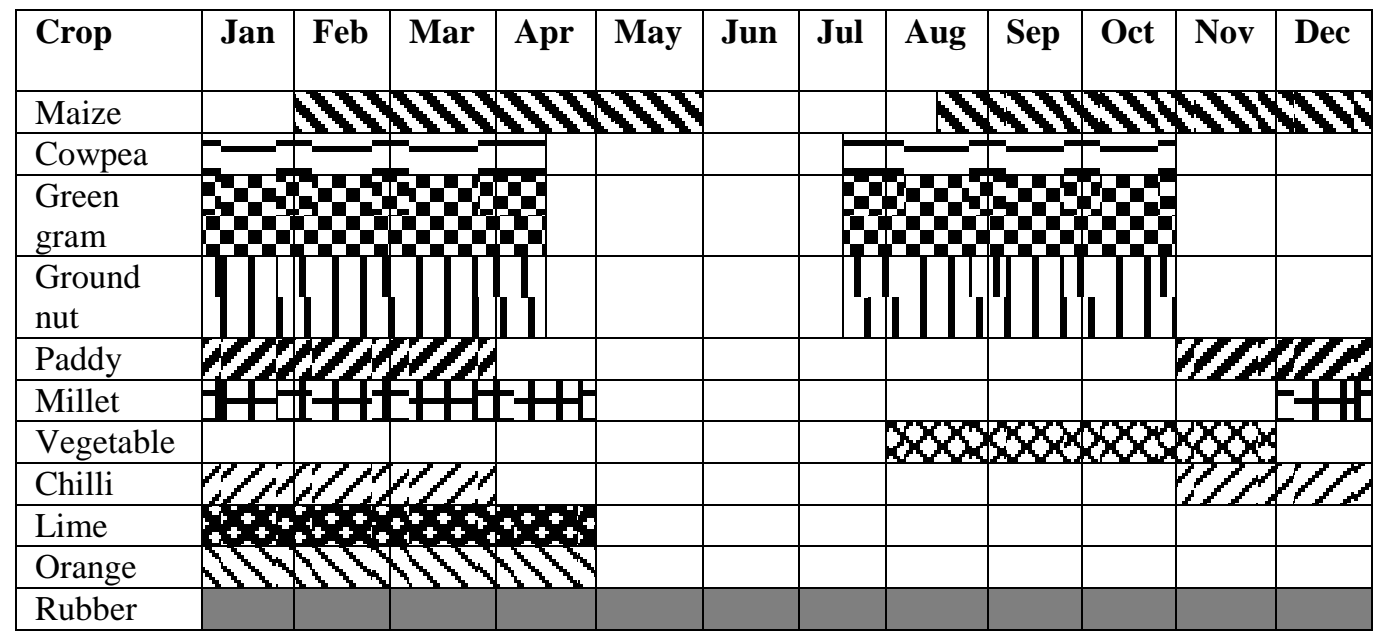

Table 2. Time allocation of farmers for agricultural activities. Information is given in terms of percentage of farmers falling into 3 categories, i.e. below 10 days, 10-20 days and above 20 days

\begin{tabular}{lccc}
\hline Month & \multicolumn{3}{c}{ Time allocation } \\
\cline { 2 - 4 } & \multicolumn{1}{c}{$\mathbf{1 0}$ days } & $\mathbf{1 0 - 2 0}$ days & $\mathbf{2 0}$ days \\
\hline January & - & 79 & 21 \\
February & - & 61 & 39 \\
March & - & 81 & 19 \\
April & - & 100 & - \\
May & 30 & 65 & 5 \\
June & 16 & 72 & 12 \\
July & - & 95 & 5 \\
August & - & 46 & 54 \\
September & - & 91 & 92 \\
October & - & 18 & 51 \\
November & - & 49 & 21 \\
December & - & 79 & \\
\hline
\end{tabular}


V H L Rodrigo et al.

Table 3. Monthly time allocation of farmers for rubber cultivation

\begin{tabular}{|c|c|c|c|c|c|c|c|c|c|c|c|c|c|}
\hline & & e & $\dot{\bar{z}}$ & $\frac{\grave{a}}{4}$ & $\sum^{\vec{E}}$ & $\Xi$ & $\Xi$ & $\stackrel{800}{Z}$ & ஜें & $\overrightarrow{\tilde{o}}$ & z & 苟 & $\sum^{\infty}$ \\
\hline $\begin{array}{l}\text { Days } \\
\text { allocated }\end{array}$ & 2 & 1 & 2 & 7 & 8 & 5 & 5 & 5 & 7 & 7 & 10 & 7 & 5.5 \\
\hline $\begin{array}{l}\% \text { from } \\
\text { agricultural } \\
\text { activities }\end{array}$ & 8 & 4.5 & 8 & 33 & 44 & 29 & 20 & 25 & 29 & 28 & 42 & 56 & 27.2 \\
\hline
\end{tabular}

Minimum level of monthly expenditure for subsistence including agricultural related activities of a family was $c a$. Rs.2,000/= and the maximum did not go beyond Rs.6,000/= (Table 4). With no much agricultural activities, the expenditure in May and June was at the minimum level. From July to September, the expenditure was at moderate level and the majority spent Rs.2,000 - 4,000/= per month. In the months of October and November, the majority were in the highest category (i.e. above Rs.4,000/=) and not a single person represented the lowest expenditure category. Expenditure was comparatively low in the months of December and January, whilst that was high in February. By April, i.e. before New Year celebration, the most of expenditure on agricultural activities tended to tail off.

Table 4. Monthly expenditure per household on subsistence and agricultural activities

\begin{tabular}{lccc}
\hline Month & \multicolumn{3}{c}{ \% Distribution of farmers } \\
\cline { 2 - 4 } & $\boldsymbol{c a}$. Rs.2,000/= & Rs. 2,000/= - 4,000/= & Rs. 4,000/= - 6,000/= \\
\hline January & 47.5 & 17.5 & 35 \\
February & 12.5 & 12.5 & 75 \\
March & 10 & 50 & 40 \\
April & 79 & 19 & 2 \\
May & 100 & - & - \\
June & 100 & - & - \\
July & - & 98 & 2 \\
August & - & 85.5 & 14.5 \\
September & - & 89.5 & 10.5 \\
October & - & 44 & 56 \\
November & - & 44 & 56 \\
December & 47.5 & 17.5 & 35 \\
\hline
\end{tabular}


Rural livelihood and rubber cultivation

Within the general expenditure, the majority of the household spent Rs. $5,000 /=$ to $15,000 /=$ per year for ailments (Table 5). There was an additional expenditure for the New Year celebration with the majority being in between Rs.5,000/= to Rs.10,000/=. Religious activities including pilgrimage have taken Rs.500- 3,000/= per month only in May and June. Also, people had to spent Rs.1,000 - 5,000/= for construction activities especially the house repairs during the period of June to August.
Each household had a minimum income of Rs.1,500 - 2,500/= per month (Table 6). In the months of March, April, October and November, the minimum level of income per month was quite high and in the range of Rs.6,000 - 10,000/=. During the period of June to August, the majority were able to obtain an additional income of Rs.5,000 - 10,000/= by engaging in hired labour activities elsewhere (Table 7).

Table 5. Expenditure per household for the activities other than agriculture

\begin{tabular}{ll}
\hline Item & Expenditure \\
\hline Subsistence & Rs. 2,000/=per month \\
Avurudu celebration (in April) & Rs.5,000/= - Rs. 10,000/= \\
Religious work (in May \& June) & Rs. 500/= - Rs. 3,000/= per month \\
Construction \& repair houses (in June, July \& August) & Rs.1,000/= - Rs. 5,000/= \\
Medicine per year & Rs.5,000/=- Rs.15,000/= \\
\hline
\end{tabular}

Table 6. Monthly income per household from agricultural activities

\begin{tabular}{lcc}
\hline \multirow{2}{*}{ Month } & \multicolumn{2}{c}{ \% Distribution of farmers } \\
\cline { 2 - 3 } & Rs.1,500/= - Rs. 2,500/= & Rs. 2,500/= - Rs.4,000/= \\
\hline January & 80 & 20 \\
February & 75 & 25 \\
May & 91 & 9 \\
June & 91 & 9 \\
July & 91 & 9 \\
August & 91 & 9 \\
September & 91 & 9 \\
December & 91 & 9 \\
& Rs. 6,000/= - Rs. 10,000/= & Rs. 10,000/= - Rs. $\mathbf{1 5 , 0 0 0 / =}$ \\
March & 95 & 5 \\
April & 95 & - \\
October & 100 & - \\
November & 100 & - \\
\hline
\end{tabular}


V H L Rodrigo et al.

Table 7. Income from non agricultural activities (on hiring labour)

\begin{tabular}{llc}
\hline & Expenditure range & \% Farmers \\
\hline $\begin{array}{l}\text { Hiring labour for } \\
\text { construction (June }-\end{array}$ & No income & 03 \\
$\begin{array}{l}\text { August) } \\
\end{array}$ & Rs.5,000/= - Rs.10,000/= & 69 \\
& Rs.10,000/= - Rs.20,000/= & 11 \\
& Rs.20,000/= - Rs.30,000/= & 17 \\
\hline
\end{tabular}

\section{Discussion}

Rural livelihood of the area selected for rubber in Eastern province was mainly dependent on rain-fed subsistence farming. Number of rainy days recorded for each month of the particular village in the present study depicted rainfall pattern given for this province before (Punyawardena, 2005). The rainfall pattern was rather unimodel with a distinct dry period during the mid part of the year. Rainy season began in October with the on set of North East monsoon and reached to the highest level in November and December time. Thereafter, few rains were received and the dry period began after April. There were two cropping seasons and both were lying within this rainy season. Farmers have selected crops considering the rainfall distribution. Some shortseason crops such as maize, cowpea, green gram and groundnut were cultivated twice a year, however farmers were careful not to plant the same crop on the same land continuously. Instead, crops were rotated in a particular land incorporating legumes to maintain the soil fertility. Maize was a major crop for which farmers tended apply fertilizer. Among the leguminous crops, cowpea and green gram were largely cultivated without any fertilizer addition. These crops were perceived to be convenient crops to farmers with less labour demand and cost. Pumpkin was cultivated only in highly fertile soils, however in general, vegetables were grown only in limited quantities particularly for own consumption as there was not a good market. Wetlands for paddy cultivation were lacking hence it was largely confined to uplands where yields were quite less than that produced in wetlands. Therefore, being the staple, paddy cultivation was mainly for subsistence.

Cash involvement in living expenditure was rather low as people's food habits mainly depended on own products. Unlike most of other communities of the country, use of imported wheat flour and chickpea (for dhal curry) was uncommon and instead, people used locally grown millet flour and green gram or cowpea, respectively. Except for minor food component like sugar, spices and some ingredients used in chewing beetle leaves (i.e. quicklime, tobacco), what spent outside the community was on non-food items such 


\section{Rural livelihood and rubber cultivation}

as medicine and oil. Most houses were illuminated with kerosene and few had solar powered electricity system. In general, overall direct expenditure per family for subsistence (including medication) was $c a$. Rs.2,000/= per month except in the months where farmers had extra expenditure for festivals. Traditional New Year in April and the religious activities in May and June (i.e. Vesak and Poson) were biggest social events in the village. This period coincided with the period of less farm activities allowing farmers to enjoy those freely. In total, $c a$. Rs.9,000/= were spent during this festival season.

Being a perennial crop, demand for labour in rubber was year-round but not as high as for seasonal crops. However, there was a competition between rubber and other crops for labour at the beginning of Maha season (i.e. September to November), if rubber planting was undertaken. Farmers mostly planted rubber in an area of $1 / 2$ or 1 acre $(0.2$ or $0.4 \mathrm{ha})$ at once and also with season crops hence time allocation to rubber had no drastic effect on subsistence agriculture. Shared labour (locally referred as Attam) among the families of the village was used for agricultural activities; hence expenditure was mainly to provide foods to the participants and to purchase fertilizer, if required. From mid April to mid July, there were no much agricultural activities and hence expenses on agriculture were distributed in rest of the period (for ca. nine months). Since the cost on subsistence per family was $c a$. Rs.2,000/= per month, additional $c a$. Rs.2,000/= would have been spent on agricultural activities during this period. Therefore, overall expenditure on agriculture per year would be $c a$. Rs.18,000/=. In addition to the expenditure on subsistence, agricultural activities and festival, on average $c a$. Rs.3,000/= per year was spent on house repairs. Therefore, total expenditure per household per year was $c a$. Rs.54,000/= (i.e. Rs.24,000 for subsistence, Rs. $18,000 /=$ for agriculture, Rs.9,000/= for festivals and Rs.3,000/= for house repairs).

End of the harvesting seasons, i.e. from March to April and from October to November, the majority earned $c a$. Rs.6,000-10,000/= per month whilst in the rest of the year, income per family from agricultural products was $c a$. Rs.2,000/= per month. On average, non agricultural activities such as hiring labour elsewhere (e.g. for construction activities) have contributed ca. Rs.8,000/= (in the range of Rs.5,000 $10,000)$. Therefore, an average family would earn $c a$. Rs.56,000/= per year (i.e. Rs. $8,000 /=\mathrm{x} 4$ months + Rs. $2,000 /=$ x 8 months + Rs. $8,000 /=)$. In addition, some resource poor families were benefited from 'Sarmurdhi' payments and that should be a big relief for these families. Total expenditure per year approximated to total income and it seemed to have some savings which would have improved their fixed assets. 


\section{H L Rodrigo et al.}

Cost on children's education was not separately assessed in the present study; however, it cannot be a large component since all students attended to the school available in the village. The livelihood of the village was rather subsistence and hence simple. Also, it was self-sufficient and highly imbedded in the SinhaleseBuddhist culture. People were openhearted; if not, it would not have been easy to gather information on expenditure and income. Every one would agree that distilleries for illicit liquor are available in most of villages in the country; however no such places were available in this particular village though one person was tapping toddy. Despite some occasional uses, not a single person in the village was addicted to alcohol. Due to the same reason, women participated in the workshop were proud of their husbands. Unfortunately, there was a newly open liquor bar in Padiyatalawa town and researchers observed that few villagers tended to buy liquor from there. Therefore, it seemed to have a danger of popularizing alcohol in the village.

Youths of some families had joined the military hence had a permanent income source. In those families, motor bikes were becoming popular and houses were refurbished or newly built. Although such youths could not spend their time on farming, their overall assets were improving. This showed the willingness of the people and their need for a permanent income source. This was particularly due to the uncertainty of rain-fed subsistence agriculture and their poor income level. Although the present study was carried out with a limited number of people who experienced in rubber so far, the situation appeared to be same in the area demarcated for future expansion of rubber in Eastern province, i.e. the Intermediate zone of the region. Being highly remunerative permanent crop, rubber will undoubtedly stabilise the household economy. At present market price, one hectare of rubber in tapping would provide an income of $c a$. Rs.1,500 per day. Therefore in future, rubber would play a significant role in the area with a paradigm shift in the local economy (Rodrigo and Iqbal, 2008). In addition, being a long-term crop, rubber cultivation secures the land ownership which is otherwise officially held by the government (Rodrigo and Iqbal, 2008). Knowing the benefits, farmers geared to cultivate rubber and that was a reason for the high level of success in the expansion process of rubber cultivation in Eastern province.

In general, rural livelihood of Eastern province was rather sustainable though operating at a low level of monitory transaction. Socio-cultural influence would play a major in this context as the fractional time allocation for social and religious activities was appreciably high (25\%) forming a strong social link. With compared to the modern lifestyle, living standards of people was poor supporting the view of rural poverty. Importantly, they have 
Rural livelihood and rubber cultivation

not been trapped with loans to obtain the luxuries in modern high consumptive society due to their sustainable mentality. Undoubtedly, living standards of the society should improve in line with the upward shift in the social status of rest of the country. However in such mechanisms to do so, care must be taken not to destroy the beneficial elements prevailing in the society. In addition to the upliftment of the household economy and living standards, environment has to be protected and therefore, rubber cultivation would be an ideal deal for the farmers in Eastern province.

\section{Acknowledgement}

We wish to thank the staff of the Rubber Research Institute of Sri Lanka and Rubber Development Department for providing necessary facilities to conduct this study. Special thanks go to Mr A M C P Jayawardena for his assistance in conducting the workshop. Financial assistance for this study was provided by the National Science Foundation under grant No. RG/2005/AG14.

\section{References}

Amaraweera, J A (1976). History of rubber cultivation for a century. Vidya (Sicence) 10, 5-14.

Central Bank of Sri Lanka (2006). Annual Report, Colombo, Sri Lanka.
Iqbal, S M M and Rodrigo, V H L (2006). Feasibility of rubber (Hevea brasiliensis Muell. Arg.) cultivation in the Eastern Province of Sri Lanka; a non traditional area for rubber. Preprints International Natural Rubber Conference. 571-584. November 2006. Ho Chi Minh city, Vietnam.

Ministry of Plantation Industries (2008). Plantation Sector Statistical Pocket Book, Planning Unit of the Ministry of Plantation Industries, Colombo, Sri Lanka.

Punyawardena, B V R (2005). Climate of the intermediate zone of Sri Lanka. In: Soils of the Intermediate Zone of Sri Lanka, (Eds. Mapa, R. B., Dassanayake A.R. and Nayakekorale, H. B.) Soil Science Society of Sri Lanka, 6-18.

Rodrigo, V H L and Iqbal, S M M (2006). Rubber (Hevea brasiliensis Muell. Arg.) cultivation in the Eastern Province of Sri Lanka with alleviation of rural poverty and increase in the forest cover: a feasibility study. International Conference on Humid Tropical Ecosystems: Changes, Challenges, Opportunities. December 2006, Kandy, Sri Lanka. Page 72.

Rodrigo, V H L and Iqbal, S M M (2008). Rubber in Eastern province; triple win to the national economy. Daily News. 23rd \& 24th April, 2008.

Rodrigo, V H L and Iqbal, S M M (2009). Potential for the expansion of rubber (Hevea brasiliensis Muell. Arg.) cultivation to Eastern province of Sri Lanka with alleviation of rural poverty and increase in the forest cover. Journal of the National Science Foundation of Sri Lanka. (In press) 


\section{H L Rodrigo et al.}

Rodrigo, V H L, Iqbal, S M M, Dharmakeerthi, R S, Karunasekera, K B A and Nugawela, A (2007). Feasibility of expanding rubber (Hevea brasiliensis Muell. Arg.) cultivation to the Eastern province of Sri Lanka. Journal of National Institute of Plantation Management 22, 25-36.
Address for correspondence: $\mathrm{Dr} \mathrm{V} \mathrm{H} \mathrm{L}$ Rodrigo, Head, Biochemistry and Physiology Dept., Rubber Research Institute of Sri Lanka, Dartonfield, Agalawatta, Sri Lanka.

E-mail: 1aksh@sltnet.lk 
